\title{
Geochemistry of Palaeoproterozoic Rocks of Aravalli Supergroup: Implications for Weathering History and Depositional Sequence
}

\author{
Pavanesh K. Singh*, M. Shamim Khan \\ Department of Geology, Aligarh Muslim University, Aligarh, India \\ Email: *singhpkalig@gmail.com
}

How to cite this paper: Singh, P.K. and Khan, M.S. (2017) Geochemistry of Palaeoproterozoic Rocks of Aravalli Supergroup: Implications for Weathering History and Depositional Sequence. International Journal of Geosciences, 8, 1278-1299. https://doi.org/10.4236/ijg.2017.810074

Received: September 23, 2017

Accepted: October 28, 2017

Published: October 31, 2017

Copyright $\odot 2017$ by authors and Scientific Research Publishing Inc. This work is licensed under the Creative Commons Attribution International License (CC BY 4.0)

http://creativecommons.org/licenses/by/4.0/

\section{(c) () Open Access}

\begin{abstract}
The Paleoproterozoic Aravalli Supregroup of rocks, hosted in Aravalli Craton of NW shield, is deposited in shallow and deep water conditions. The major lithologies are phyllites and quartzites with significant components of greywacks and dolomite. Geochemical indices in particular, CIA (Chemical Index of Alteration) values (avg. phyllites: 51.6 - 81.5, avg. quartzites: 57.4 - 95.5) calculated from the data of clastic rocks of ASG suggest minimum to highly intense weathering in the source region. Other indices including PIA, CIW and ICV along with plot patterns on the A-CN-K diagram also nearly endorse CIA based interpretation. These rocks possess relatively high $\mathrm{Th} / \mathrm{U}$ ratios compared to that found in fresh igneous rocks or their high grade metamorphic equivalents. This high $\mathrm{Th} / \mathrm{U}$ ratio is neither a source inheritance nor a result of oxidation state rather a manifestation of Th hosting mineral accumulation through sorting. Viewed in the context of present stratigraphic succession, the weathering history adduced from geochemistry does not seem compatible but matches well with earlier classification scheme wherein the evolution of Aravalli Supergroup was considered episodic.
\end{abstract}

\section{Keywords}

Clastic Geochemistry, Aravalli Supergroup, Rajasthan, Palaeoweathering, Indian Shield

\section{Introduction}

Sedimentary rocks are of great interest since quite long time as they have been effectively used in unfolding the history of diverse geological settings. Clastic material can be act upon through different practices and observations. The chemical and mineralogical compositions of clastic sedimentary rocks are directed 
by many factors including, transportation mechanism, composition of the source rocks, environmental parameters, duration and intensity of weathering, depositional environment and post depositional makeup (e.g., diagenesis and metamorphism) [1]. Among all these aspects, the main controlling features are source rock composition [2] [3] and the tectonic setting of the sedimentary basin [4]. Nevertheless, secondary processes could also modify the composition of final deposit [5] [6]. Extensive work has been done on the above aspects, in particular on genesis of siliciclastic sediments across globe [7]-[17].

Aravalli craton of NW Indian shield preserves thickest and extensively developed Proterozoic sedimentary sequence [18]. These sequences crop out in two linear belts namely Paleoproterozoic Aravalli fold belt and Mesoproterozoic Delhi fold belt. Trans-Aravalli region hosts Neo-proterozoic sediments [19]. However, despite possessing large volume of clastic material, the study of Paleoproterozoic Aravalli fold belt remained largely restricted to its magmatic components to infer genesis and crustal evolution of Aravalli Craton [20] [21] [22] [23]. There are few studies which employed clastic rocks for some geological aspects [24] [25]. The present study is the maiden attempt wherein a comprehensive account of weathering history is presented on the basis of major and trace elements of entire clastic litho-spectrum of Aravalli fold belt.

\section{Geological Setting}

The Aravalli Mountain range is the main edifice of the Aravalli craton of northwest Indian shield. It extends over $700 \mathrm{~km}$ in length, with a general NE-SW trend. It is composed of a Neoarchaean cratonic nucleus [26] [27] [28] [29] and two major Proterozoic orogenic belts. The cratonic nucleus is made up of tonalite-trondhjhemite-granodiorite (TTG) gneisses, intrusive granitoids and metavolcanic units with minor metasedimentary rocks, collectively designated as Banded Gneissic Complex (BGC) [30]. The Proterozoic orogenic belts (viz., Aravalli and Delhi fold belts) preserve supracrustal sedimentary sequences designated as Aravalli Supergroup and Delhi Supergroup respectively.

The rocks of Paleoproterozoic Aravalli Supergroup cover a wide region in the eastern and south-eastern parts of the Aravalli Mountain Range. The entire region can be divided from north to south into three sectors; 1) the Bhilwara sector; 2) Udaipur sector; 3) Lunavada sector. Out of these three sectors, the Udaipur sector is known as the type area of Aravalli Supergroup where they show evidence of complete development of stratigraphic succession and structural evolution. The rocks of the Udaipur sector characteristically show two contrasting sedimentary facies associations which are distributed along two roughly N-E trending belts (Figure 1). The eastern belt represents a shelf sequence, wherein carbonate rocks are the dominant component. The western belt, by contrast, is characterized by a carbonate free, pelite-dominated sequence with thin intercalated arenites. The two sedimentary associations correspond to a near shore shelf facies and a deep-sea or distal facies respectively [31] [32] [33] [34] [35]. The unconformable contact between the basement BGC and Aravalli 


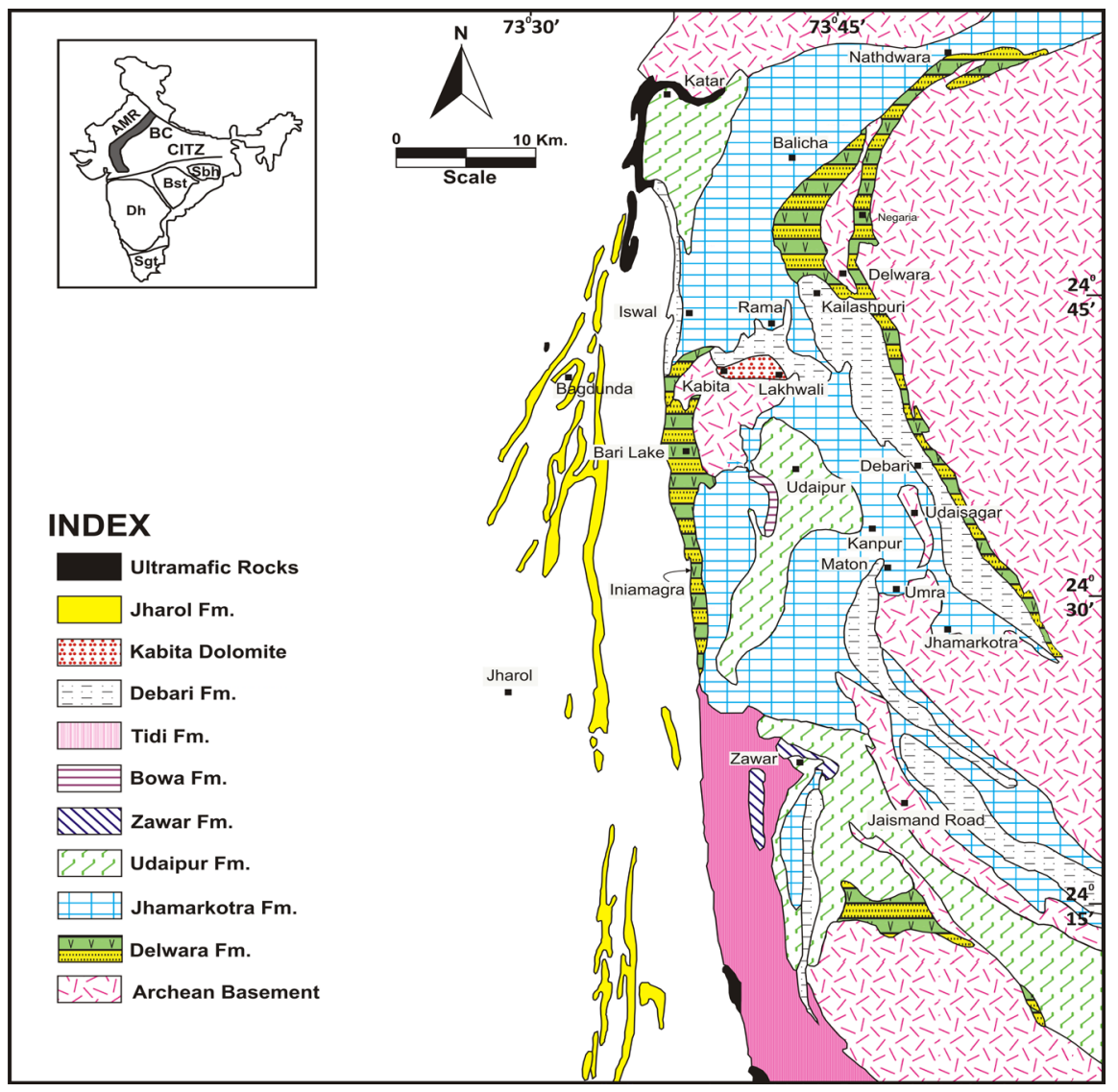

Figure 1. Geological map of the Udaipur and Jharol belts showing the distribution of the rocks of Aravalli Supergroup (Simplified after reference [34] and [38]. Inset shows the location of Aravalli mountain range in India. AMR-Aravalli Mountain Range, BCBundelkhand Craton, CITZ-Central Indian Thrust Zone, Sbh-Singhbhum Craton, Bst- Bastar Craton, Dh-Dharwar Craton, Sgt-Southern Granulitic Terrain.

Supergroup is characterized by the presence of alumina-rich and iron-poor palaeosols [36] suggesting large hiatus before the initiation of Aravalli sedimentation [34]. Roy [37] proposed a three-fold classification for the Aravalli Supergroup (Lower, Middle and Upper Aravalli), on the basis of unconformity bounded litho-assemblages.

The Lower Aravalli Group is constituted by the rocks of Delwara and Jhamarkotra formations. Basal Delwara Formation is made up of an intercalated sequence of metabasaltic rocks and well-sorted feldspathic quartzites whereas Jhamarkotra Formation comprises dolomites, carbonaceous phyllites with intercalated quartzites. The Middle Aravalli Group commences with deep water turbidite sequences of the Udaipur Formation comprising metagreywacke and phyllite, indicating deepening of the carbonate platform and active tectonism. Udaipur Formation is overlain by thick rock sequences namely dolomite (intermittent phyllite/quartzite), quartzite (intermittent phyllite), and phyllite-dolomite-quartzite, grouped respectively as Mochia (Zawar), Bowa and Tidi formations in continuous succession. Debari quartzites and Kabita dolomites constitute Upper Aravalli Group whereas Jharol Formation comprising mica schists 
and ultramafics represent western deep facies sequence of the Aravalli basin [38].

\section{Sample Preparation and Analytical Techniques}

Seventy four samples for major and forty two samples for trace elements of quartzites and phyllites representing various formations of Aravalli Supergroup were analysed and the results are presented in Table 1. Fresh Samples were selected after thin section screening and grounded up to 200 meshes using a steel mortar. Major element oxides were analysed by X-ray fluorescence techniques in the geochemical laboratory of National Institute of Oceanography, Goa, India. Trace elements were analysed by Inductively Coupled Plasma Mass Spectrometer (ICP-MS) at Indian Institute of Technology, Kanpur and National Geophysical Research Institute, Hyderabad, India.

\section{Results}

\subsection{Major Elements}

Compositionally, the average contents of major oxides classify the quartzites of Aravalli Supergroup as quartzarenite $\left(\mathrm{SiO}_{2}: 91.53 \%, \mathrm{Al}_{2} \mathrm{O}_{3}: 4.49 \%, \mathrm{Fe}_{2} \mathrm{O}_{3}: 0.90 \%\right.$, $\mathrm{CaO}: 0.70 \%, \mathrm{Na}_{2} \mathrm{O}: 1.06 \%$ and $\mathrm{K}_{2} \mathrm{O}: 0.73 \%$ ) except few samples (Condie, 1993).; The Delwara Quartzites contain lowest silica (avg. 83.73\%) and highest alumina (avg. 9.53\%) contents whereas the Debari Quartzites posses highest silica (avg. 96.18\%) and lowest alumina (avg. 2.58\%) abundances. The average $\mathrm{Na}_{2} \mathrm{O}$ concentration of the quartzites of Udaipur belt (shallow facies) ranges between 0.01 to $3.26 \%$. It could be due to the inconsistent presence of $\mathrm{Na}$ rich plagioclase in the different formations. Deep water Jharol Quartzites have low $\mathrm{Na}_{2} \mathrm{O}$ content $(<1 \%)$ compatible to low plagioclase in their petrographic mode. Upper continental crust (UCC) normalized spidergrams of quartzites show depletion in all major oxides except $\mathrm{SiO}_{2}$. The magnitude of depletion is maximum in Tidi Quartzites and minimum in Delwara Quartzites (Figure 2).

Among the various formations of Aravalli Supergroup, $\mathrm{SiO}_{2}$ content is maximum in Zawar Phyllites (avg. 71.47\%) and minimum in Delwara Phyllites (avg. 55.99\%) whereas the $\mathrm{Al}_{2} \mathrm{O}_{3}$ abundances are maximum in Jharol Phyllite (avg. 21.66\%) and minimum in Delwara Phyllite (avg. 11.58\%). However, the Delwara Phyllites have higher contents of $\mathrm{Fe}_{2} \mathrm{O}_{3}$ (avg. 14.42\%) and $\mathrm{CaO}$ (avg. 6.35\%). The $\mathrm{SiO}_{2}$ concentrations of the Udaipur and Jharol Phyllites are almost same (avg. $65.79 \%$ \& $64.47 \%$ respectively) but they differ in their $\mathrm{Al}_{2} \mathrm{O}_{3}$ abundances as the former is depleted (avg.18.24\%) relative to later (avg. 21.66\%) (Table 1). Compared to PAAS, phyllites are depleted in all major oxides but Delwara and Bowa Phyllites show enriched abundances. Delwara Phyllites are enriched in $\mathrm{Ti}, \mathrm{Fe}$, $\mathrm{Mg}, \mathrm{Ca}$ and $\mathrm{Na}$ whereas Bowa Phyllites are enriched in $\mathrm{Na}$ but severely depleted in $\mathrm{K}$ (Figure 2).

The general correlation matrix for clastic rocks indicates that $\mathrm{Al}_{2} \mathrm{O}_{3}$ is in general positively correlated with chief major oxides $\left(\mathrm{MgO}, \mathrm{TiO}_{2}, \mathrm{~K}_{2} \mathrm{O}\right.$ and $\left.\mathrm{Na}_{2} \mathrm{O}\right)$ 


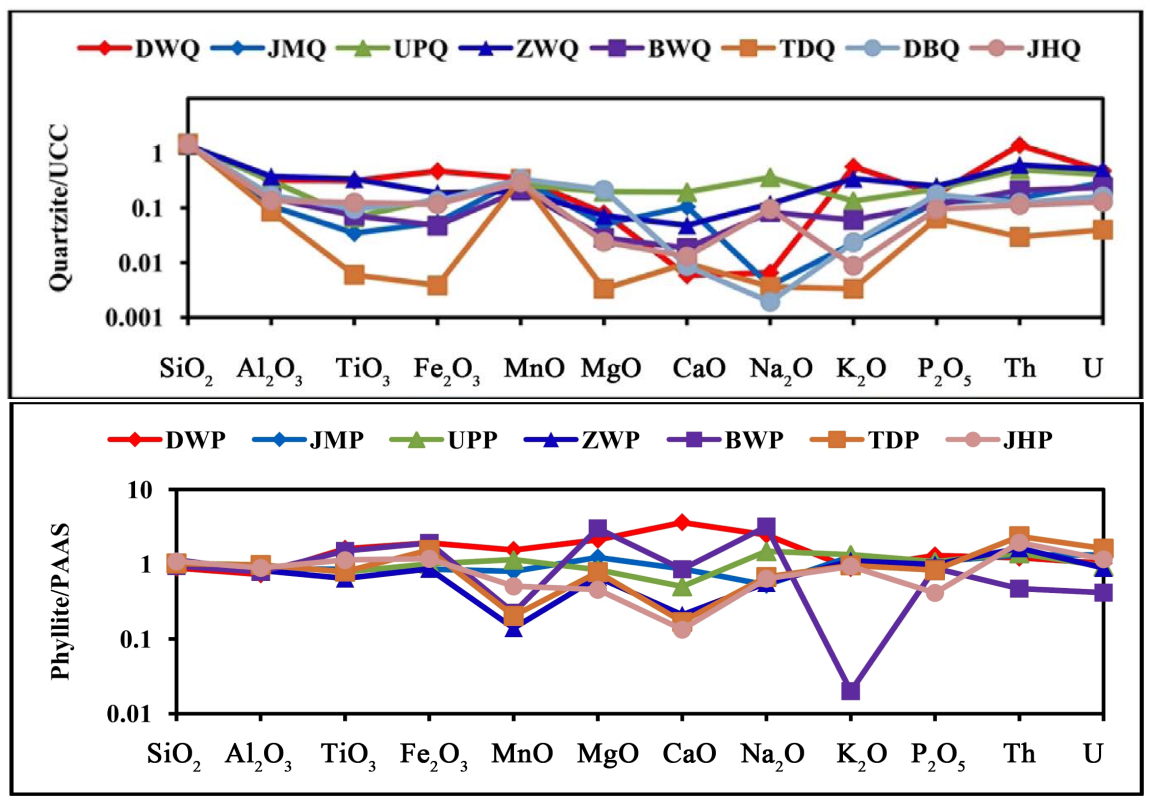

Figure 2. Average Upper Continental Crust (normalizing values after reference [9]) and Post Archean Average Australian Shale (normalizing values after reference [3]) normalized multi-element spider diagrams for quartzites and phyllites of Aravalli Supergroup.

but shows negative variation with $\mathrm{SiO}_{2}$ in both types of Aravalli clastics. Furthermore, $\mathrm{Al}_{2} \mathrm{O}_{3}$ is also in good positive correlation with Th and $\mathrm{U}$. This indicates that the chemical composition of the Aravalli clastics is nearly primary. Minor inconsistencies in some samples of phyllites and quartzites may be due to post depositional effects (Table 1).

\subsection{Palaeoweathering}

Palaeoweathering in source area is one of the most important processes affecting the composition of clastic sedimentary rocks. To constrain the intensity of chemical weathering in the source area, the geoscientists have employed several indices e.g., Chemical Index of Alteration (CIA) [13], Plagioclase Index of Alteration (PIA) [39], Chemical Index of Weathering (CIW) [40], Index of Compositional Variability (ICV) [41], Ruxton Weathering Index (R) [42], Vogt Residual Index (V) [43], the Weathering Index (of Parker) (WIP) [44] etc. In this study, we used those indices and ratios which have wider acceptance in geoscientist fraternity in the interpretation of weathering in the source area.

\subsection{Chemical Index of Alteration (CIA)}

It is considered one of the most useful indices to ascertain and quantify the intensity of chemical weathering. The index is calculated as follows:

$$
\mathrm{CIA}=\left[\mathrm{Al}_{2} \mathrm{O}_{3} / \mathrm{Al}_{2} \mathrm{O}_{3}+\mathrm{CaO}^{*}+\mathrm{Na}_{2} \mathrm{O}+\mathrm{K}_{2} \mathrm{O}\right] \times 100
$$

The values of oxides are in molecular proportions and $\mathrm{CaO}^{*}$ represents $\mathrm{CaO}$ in silicate minerals. This weathering index is not only related to the degree of 
Table 1. Correlation coefficient matrix for clastic rocks of Aravalli Supergroup.

\begin{tabular}{|c|c|c|c|c|c|c|c|c|c|c|}
\hline \multicolumn{11}{|c|}{ Lower Aravalli Quartzite } \\
\hline & $\mathrm{SiO}_{2}$ & $\mathrm{Al}_{2} \mathrm{O}_{3}$ & $\mathrm{TiO}_{2}$ & $\mathrm{Fe}_{2} \mathrm{O}_{3}$ & $\mathrm{MgO}$ & $\mathrm{CaO}$ & $\mathrm{Na}_{2} \mathrm{O}$ & $\mathrm{K}_{2} \mathrm{O}$ & Th & $\mathrm{U}$ \\
\hline $\mathrm{SiO}_{2}$ & 1 & & & & & & & & & \\
\hline $\mathrm{Al}_{2} \mathrm{O}_{3}$ & -0.70 & 1 & & & & & & & & \\
\hline $\mathrm{TiO}_{2}$ & -0.36 & 0.29 & 1 & & & & & & & \\
\hline $\mathrm{Fe}_{2} \mathrm{O}_{3}$ & -0.70 & 0.09 & 0.57 & 1 & & & & & & \\
\hline $\mathrm{MgO}$ & -0.68 & -0.05 & 0.17 & 0.88 & 1 & & & & & \\
\hline $\mathrm{CaO}$ & -0.71 & 0.00 & 0.10 & 0.83 & 0.98 & 1 & & & & \\
\hline $\mathrm{Na}_{2} \mathrm{O}$ & -0.62 & 0.96 & 0.03 & -0.09 & -0.11 & -0.04 & 1 & & & \\
\hline $\mathrm{K}_{2} \mathrm{O}$ & -0.46 & 0.53 & 0.93 & 0.48 & 0.05 & 0.02 & 0.28 & 1 & & \\
\hline $\mathrm{Th}$ & -0.84 & 0.89 & 0.82 & 0.89 & 0.43 & -0.33 & 0.25 & 0.89 & 1 & \\
\hline $\mathrm{U}$ & -0.23 & 0.44 & 0.39 & 0.46 & 0.35 & -0.85 & 0.22 & 0.45 & 0.57 & 1 \\
\hline
\end{tabular}

\section{Middle Aravalli Quartzite}

\begin{tabular}{ccccccccccc}
\hline & $\mathrm{SiO}_{2}$ & $\mathrm{Al}_{2} \mathrm{O}_{3}$ & $\mathrm{TiO}_{2}$ & $\mathrm{Fe}_{2} \mathrm{O}_{3}$ & $\mathrm{MgO}$ & $\mathrm{CaO}$ & $\mathrm{Na}_{2} \mathrm{O}$ & $\mathrm{K}_{2} \mathrm{O}$ & $\mathrm{Th}$ & $\mathrm{U}$ \\
\hline $\mathrm{SiO}_{2}$ & 1 & & & & & & & & & \\
$\mathrm{Al}_{2} \mathrm{O}_{3}$ & -0.98 & 1 & & & & & & & & \\
$\mathrm{TiO}_{2}$ & -0.81 & 0.72 & 1 & & & & & & & \\
$\mathrm{Fe}_{2} \mathrm{O}_{3}$ & -0.84 & 0.74 & 0.98 & 1 & & & & & & \\
$\mathrm{MgO}$ & -0.79 & 0.67 & 0.87 & 0.94 & 1 & & & & & \\
$\mathrm{CaO}$ & -0.65 & 0.60 & 0.39 & 0.52 & 0.74 & 1 & & & & \\
$\mathrm{Na}_{2} \mathrm{O}$ & -0.97 & 0.98 & 0.66 & 0.71 & 0.68 & 0.68 & 1 & & & \\
$\mathrm{~K}_{2} \mathrm{O}$ & -0.90 & 0.93 & 0.72 & 0.69 & 0.51 & 0.30 & 0.87 & 1 & & \\
$\mathrm{Th}$ & -0.74 & 0.75 & 0.64 & 0.90 & 0.64 & 0.67 & 0.64 & 0.79 & 1 & \\
$\mathrm{U}$ & -0.38 & 0.38 & 0.48 & 0.62 & 0.29 & 0.33 & 0.26 & 0.50 & 0.88 & 1 \\
\hline
\end{tabular}

\begin{tabular}{|c|c|c|c|c|c|c|c|c|c|c|}
\hline \multicolumn{11}{|c|}{ Upper Aravalli Quartzite } \\
\hline & $\mathrm{SiO}_{2}$ & $\mathrm{Al}_{2} \mathrm{O}_{3}$ & $\mathrm{TiO}_{2}$ & $\mathrm{Fe}_{2} \mathrm{O}_{3}$ & $\mathrm{MgO}$ & $\mathrm{CaO}$ & $\mathrm{Na}_{2} \mathrm{O}$ & $\mathrm{K}_{2} \mathrm{O}$ & $\mathrm{Th}$ & $\mathrm{U}$ \\
\hline $\mathrm{SiO}_{2}$ & 1 & & & & & & & & & \\
\hline $\mathrm{Al}_{2} \mathrm{O}_{3}$ & -0.95 & 1 & & & & & & & & \\
\hline $\mathrm{TiO}_{2}$ & -0.91 & 0.79 & 1 & & & & & & & \\
\hline $\mathrm{Fe}_{2} \mathrm{O}_{3}$ & -0.91 & 0.95 & 0.88 & 1 & & & & & & \\
\hline $\mathrm{MgO}$ & -0.12 & -0.02 & -0.10 & -0.28 & 1 & & & & & \\
\hline $\mathrm{CaO}$ & -0.75 & 0.51 & 0.89 & 0.57 & 0.22 & 1 & & & & \\
\hline $\mathrm{Na}_{2} \mathrm{O}$ & -0.64 & 0.45 & 0.90 & 0.65 & -0.26 & 0.88 & 1 & & & \\
\hline $\mathrm{K}_{2} \mathrm{O}$ & -0.65 & 0.86 & 0.40 & 0.77 & -0.19 & -0.01 & 0.01 & 1 & & \\
\hline Th & -0.89 & 0.93 & 0.87 & 1.00 & -0.33 & 0.55 & 0.65 & 0.76 & 1 & \\
\hline $\mathrm{U}$ & -1.00 & 0.94 & 0.94 & 0.92 & 0.07 & 0.78 & 0.69 & 0.62 & 0.91 & 1 \\
\hline
\end{tabular}




\begin{tabular}{|c|c|c|c|c|c|c|c|c|c|c|}
\hline \multicolumn{11}{|c|}{ Lower Aravalli Phyllite } \\
\hline & $\mathrm{SiO}_{2}$ & $\mathrm{Al}_{2} \mathrm{O}_{3}$ & $\mathrm{TiO}_{2}$ & $\mathrm{Fe}_{2} \mathrm{O}_{3}$ & $\mathrm{MgO}$ & $\mathrm{CaO}$ & $\mathrm{Na}_{2} \mathrm{O}$ & $\mathrm{K}_{2} \mathrm{O}$ & Th & $\mathrm{U}$ \\
\hline $\mathrm{SiO}_{2}$ & 1 & & & & & & & & & \\
\hline $\mathrm{Al}_{2} \mathrm{O}_{3}$ & -0.18 & 1 & & & & & & & & \\
\hline $\mathrm{TiO}_{2}$ & -0.68 & 0.10 & 1 & & & & & & & \\
\hline $\mathrm{Fe}_{2} \mathrm{O}_{3}$ & -0.75 & -0.33 & 0.58 & 1 & & & & & & \\
\hline $\mathrm{MgO}$ & -0.84 & -0.13 & 0.47 & 0.76 & 1 & & & & & \\
\hline $\mathrm{CaO}$ & -0.64 & -0.43 & 0.38 & 0.56 & 0.60 & 1 & & & & \\
\hline $\mathrm{Na}_{2} \mathrm{O}$ & -0.59 & -0.04 & 0.52 & 0.42 & 0.35 & 0.59 & 1 & & & \\
\hline $\mathrm{K}_{2} \mathrm{O}$ & 0.25 & 0.71 & -0.24 & -0.69 & -0.44 & -0.54 & -0.39 & 1 & & \\
\hline Th & 0.46 & 0.01 & -0.65 & -0.45 & -0.59 & -0.55 & -0.42 & 0.62 & 1 & \\
\hline $\mathrm{U}$ & 0.57 & -0.01 & -0.39 & -0.68 & -0.65 & -0.41 & -0.36 & 0.31 & 0.40 & 1 \\
\hline
\end{tabular}

\section{Middle Aravalli Phyllite}

\begin{tabular}{ccccccccccc}
\hline & $\mathrm{SiO}_{2}$ & $\mathrm{Al}_{2} \mathrm{O}_{3}$ & $\mathrm{TiO}_{2}$ & $\mathrm{Fe}_{2} \mathrm{O}_{3}$ & $\mathrm{MgO}$ & $\mathrm{CaO}$ & $\mathrm{Na}_{2} \mathrm{O}$ & $\mathrm{K}_{2} \mathrm{O}$ & $\mathrm{Th}$ & $\mathrm{U}$ \\
\hline $\mathrm{SiO}_{2}$ & 1 & & & & & & & & & \\
$\mathrm{Al}_{2} \mathrm{O}_{3}$ & -0.40 & 1 & & & & & & & & \\
$\mathrm{TiO}_{2}$ & -0.51 & 0.58 & 1 & & & & & & & \\
$\mathrm{Fe}_{2} \mathrm{O}_{3}$ & -0.73 & -0.24 & 0.12 & 1 & & & & & & \\
$\mathrm{MgO}$ & -0.57 & -0.39 & -0.17 & 0.76 & 1 & & & & & \\
$\mathrm{CaO}$ & -0.16 & -0.26 & 0.09 & 0.28 & 0.09 & 1 & & & & \\
$\mathrm{Na}{ }_{2} \mathrm{O}$ & 0.05 & -0.19 & 0.21 & -0.02 & -0.04 & 0.18 & 1 & & & \\
$\mathrm{~K}_{2} \mathrm{O}$ & -0.06 & 0.63 & 0.27 & -0.43 & -0.52 & -0.11 & -0.53 & 1 & & \\
$\mathrm{Th}$ & 0.05 & 0.27 & -0.30 & 0.00 & -0.61 & -0.33 & -0.44 & 0.31 & 1 & \\
$\mathrm{U}$ & -0.06 & 0.35 & -0.20 & 0.00 & -0.57 & -0.46 & -0.22 & 0.26 & 0.85 & 1 \\
\hline
\end{tabular}

Upper Aravalli Phyllite

\begin{tabular}{ccccccccccc}
\hline & $\mathrm{SiO}_{2}$ & $\mathrm{Al}_{2} \mathrm{O}_{3}$ & $\mathrm{TiO}_{2}$ & $\mathrm{Fe}_{2} \mathrm{O}_{3}$ & $\mathrm{MgO}$ & $\mathrm{CaO}$ & $\mathrm{Na}_{2} \mathrm{O}$ & $\mathrm{K}_{2} \mathrm{O}$ & $\mathrm{Th}$ & $\mathrm{U}$ \\
\hline $\mathrm{SiO}_{2}$ & 1 & & & & & & & & \\
$\mathrm{Al}_{2} \mathrm{O}_{3}$ & -0.83 & 1 & & & & & & & \\
$\mathrm{TiO}_{2}$ & -0.45 & 0.04 & 1 & & & & & & \\
$\mathrm{Fe}_{2} \mathrm{O}_{3}$ & -0.19 & -0.37 & 0.51 & 1 & & & & & & \\
$\mathrm{MgO}$ & -0.82 & 0.42 & 0.46 & 0.61 & 1 & & & & \\
$\mathrm{CaO}$ & 0.45 & -0.06 & -0.95 & -0.55 & -0.40 & 1 & & & \\
$\mathrm{Na} \mathrm{O}_{2} \mathrm{O}$ & -0.63 & 0.22 & 0.52 & 0.58 & 0.91 & -0.34 & 1 & & & \\
$\mathrm{~K}_{2} \mathrm{O}$ & -0.96 & 0.72 & 0.68 & 0.26 & 0.77 & -0.68 & 0.63 & 1 & & \\
$\mathrm{Th}$ & -0.53 & 0.84 & 0.94 & -0.92 & -0.80 & -0.92 & -0.53 & 0.82 & 1 & \\
$\mathrm{U}$ & -0.48 & 0.81 & 0.93 & -0.90 & -0.83 & -0.94 & -0.57 & 0.80 & 1 & 1 \\
\hline
\end{tabular}


weathering but also controlled by source composition and grain size. The source rocks with felsic composition have greater CIA values than mafic ones. Selective removal of cations (e.g. $\mathrm{Ca}^{2+}, \mathrm{Na}^{+}, \mathrm{K}^{+}$) over stable residual constituents $\left(\mathrm{Al}^{3+}\right.$, $\mathrm{Ti}^{4+}$ ) during weathering in a warm and humid climate results in high CIA values [39] [13]. Near absence of chemical alteration results in low CIA values, which may reflect cool and/or arid conditions or alternatively rapid physical weathering and erosion under an active tectonic setting [39] [45] [46] [47]. CIA values of unweathered igneous rocks and fresh feldspar range from 40 - 50, whereas in intensely weathered residue, it approaches to 100 [13]. The CIA value of PAAS is reported to be 70 - 75 which is considered to represent low to moderate degree of weathering. CIA values for the unaltered plagioclase and K-feldspar are approximately equal to 50 and value of 100 indicates complete conversion of feldspars to clay minerals like gibbsite and kaolinite [39].

Average CIA values of the phyllites of Aravalli Supergroup range from 51.6 to 81.5 (DWP-Delwara Phyllites: 51.6, JKP-Jhamarkotra Phyllites: 64.9, UPPUdaipur Phyllites: 66.2, ZWP-Zawar Phyllites: 71.5, BWP-Bowa Phyllites: 81.5, TDP—Tidi Phyllites: 71.4, JHP_Jharol Phyllites: 76.3). It is evident from CIA values of phyllites of different formation that chemical weathering of Aravalli Supergroup increased with stratigraphic younging except the Bowa Phyllites which possess highest CIA values, although these phyllites are not at top in stratigraphic hierarchy (Figure 1). The CIA variation of quartzites in general follows the phyllitic trend. The range of variation of average CIA values of quartzites of Aravalli Supergroup is 57.4 - 95.5 (DWQ-Delwara Quartzites: 57.4, JMQ-Jhamarkotra Quartzites: 63.7, UPQ-Udaipur Quartzites: 67.0, ZWQZawar Quartzites: 67.6, BWQ-Bowa Quartzites: 78.9, TDQ-Tidi Quartzites: 95.5, DBQ-Debari Quartzites: 95.3 and JHQ-Jharol Quartzites: 81.6). Average CIA values of the quartzites also endorse the interpretation adduced from the phyllites that the chemical weathering progressively increases from base to top, i.e. Delwara clastics are product of least chemical weathering whereas the sediments of upper formations resulted from intense chemical weathering.

\subsection{Chemical Index of Weathering (CIW)}

Harnois (1988) [40] proposed that weathering index should be calculated with those elements which show consistent geochemical behaviour during weathering and which are not affected by the degree of oxidation of the weathered material. Accordingly, he proposed chemical index of weathering (CIW) (also called as ACNRATIO) which is calculated by given formula where all the oxides are in molecular proportions.

$$
\mathrm{CIW}=\left[\mathrm{Al}_{2} \mathrm{O}_{3} /\left(\mathrm{Al}_{2} \mathrm{O}_{3}+\mathrm{CaO}+\mathrm{Na}_{2} \mathrm{O}\right)\right] \times 100
$$

In this index $\mathrm{Al}_{2} \mathrm{O}_{3}$ is used as immobile element that remains in the system as proposed in earlier indices whereas $\mathrm{CaO}$ and $\mathrm{Na}_{2} \mathrm{O}$ are the mobile components as they are readily leached during weathering. This index is alike to the CIA except to the elimination of $\mathrm{K}_{2} \mathrm{O}$. Maynard [48] also employed the same formulation 
and other workers used $\mathrm{K}_{2} \mathrm{O}$ free CIA (CIA-K). Similar to the CIA, the CIW also measures the degree of chemical weathering and conversion of feldspar into clays[14] [39] [49] [50]. This equation is more appropriate in understanding the extent of plagioclase alteration alone since $\mathrm{K}_{2} \mathrm{O}$ is subtracted from $\mathrm{Al}_{2} \mathrm{O}_{3}$ in the numerator and denominator of the CIA equation. However, Fedo et al. (1995) [39] argued that the use of CIW calculation to quantify chemical weathering intensity is inappropriate and should be used with caution since the equation provides values of 80 for unweathered potassic granite and values close to 100 for clay minerals such as kaolinite, illite and gibbsite, similar to values found for residual products of CIW for smectite, 80; kaolinite, illite and gibbsite, 100. The CIA and CIW are interpreted in similar way with a value of 50 for unweathered upper continental crust and about 100 for highly weathered materials with complete removal of alkali and alkaline-earth elements [12] [51] [52]. Nevertheless, CIW is still considered a better index than CIA by many workers as it does not incorporate $\mathrm{K}_{2} \mathrm{O}$ content and thus eliminate the possibility of $\mathrm{K}$-metasomatism. With the depletion of $\mathrm{Na}$ and $\mathrm{Ca}$ in relation to $\mathrm{Al}$ during weathering the value of CIA increased for sediments.

The average CIW values of phyllites of Aravalli Supergroup ranging from 56.9 to 93.3 (DWP: 56.9, JMP: 82.9, UPP: 87.7, ZWP: 92, BWP: 81.7, TDP: 88, JHP: 93.3) advocate for least to intense chemical weathering. Similarly, average CIW values of quartzites of Aravalli Supergroup ranging from 67 to 99.1 (DWQ: 75.5, JMQ: 67.0, UPQ: 76.0, ZWQ: 83.5, BWQ: 85.5, TDQ: 96.6, DBQ: 99.1, JHQ: 82.4) nearly duplicate the phyllite trend.

\subsection{Plagioclase Index of Alteration (PIA)}

Plagioclase Index of Alteration (PIA) has been used as an alternative to CIW. It is used to monitor the weathering of the plagioclase [39] in silicate rocks as the mineral has higher abundance in the clastic rocks derived from basic igneous rocks and it also possesses high dissolution nature. The value of PIA can be calculated by given formula

$$
\mathrm{PIA}=\left[\left(\mathrm{Al}_{2} \mathrm{O}_{3}-\mathrm{K}_{2} \mathrm{O}\right) /\left(\mathrm{Al}_{2} \mathrm{O}_{3}+\mathrm{CaO}^{*}+\mathrm{Na}_{2} \mathrm{O}-\mathrm{K}_{2} \mathrm{O}\right)\right] \times 100
$$

All the oxides of this formula are in molecular proportions and $\mathrm{CaO}^{*}$ is the $\mathrm{CaO}$ content incorporated in silicate minerals only. Like CIA and CIW, PIA around 50 suggests derivation of detritus from fresh rocks and values closer to 100 indicate the complete conversion of plagioclase into clay minerals [39]. PAAS has PIA values of 79. The average PIA values of phyllites of Aravalli Supergroup range from 51.4 to 90.9 (DWP: 51.4, JMP: 78.8, UPP: 84.9, ZWP: 89.4, BWP: 81.6, TDP: 84.4, JHP: 90.9). Average PIA values of quartzites of Aravalli Supergroup range from 65.8 to 99 (DWQ: 73.5, JMQ: 65.8, UPQ: 70.9, ZWQ: 78.5, BWQ: 84.8, TDQ: 96.6, DBQ: 99.0, JHQ: 82.1). The PIA values of Aravalli clastics suggests that initially the source rock(s) undergone relatively small degree of chemical weathering which became quite intense with the passage of time which significantly converted plagioclase into clay minerals. 


\subsection{Index of Compositional Variability}

Index of compositional variability (ICV) ratio is used to access the original detrital mineralogy [41] [53]. The ratio of the oxides is useful to differentiate between clay and non-clay bearing minerals [53]. ICV is defined as

$$
\mathrm{ICV}=\left(\mathrm{Fe}_{2} \mathrm{O}_{3}+\mathrm{Na}_{2} \mathrm{O}+\mathrm{CaO}+\mathrm{MgO}+\mathrm{MnO}+\mathrm{K}_{2} \mathrm{O}+\mathrm{TiO}_{2}\right) / \mathrm{Al}_{2} \mathrm{O}_{3}
$$

ICV is used to measure the abundance of alumina in relation to the other major oxides. The clay minerals owing to their higher $\mathrm{Al}$ content possess lower ICV whereas non clay silicate minerals contain higher proportion of silica and lower amount of alumina as compared to the clay minerals. The ICV decreases in the order of pyroxene and amphibole $(\sim 10-100)$, biotite $(\sim 8)$, alkali feldspar $(\sim 0.8$ $1)$, plagioclase $(\sim 0.6)$, muscovite and illite $(\sim 0.3)$, montmorillonite $(\sim 0.15$ $0.03)$, and kaolinite $(\sim 0.03-0.05)$ [10]. Thus, immature shales with a high percentage of non-clay silicate minerals will contain ICV values $>1.0$ whereas mature sediments dominated by clay minerals show ICV value $<1.0$ [53]. The average ICV values of phyllites of Aravalli Supergroup range from 1.1 to 4.3 (DWP: 4.3, JMP: 2.1, UPP: 1.6, ZWP: 1.1, BWP: 3.6, TDP: 1.4, JHP: 1.1), whereas those of quartzites range from 0.1 to 1.9 (DWQ: 1.2, JMQ: 1.9, UPQ: 1.0, ZWQ: 0.8, BWQ: 0.5, TDQ: 0.1, DBQ: 0.9, JHQ: 0.6). It is again evident from above data that ICV values are higher in older formations and lower in younger formations. It suggests that the immaturity of clastic rocks of Aravalli Supergroup decreased up the sequence and in turn advocates for a progressive change in transport distance or stabilisation of source area.

\subsection{Th/U Ratio}

The $\mathrm{Th} / \mathrm{U}$ ratio of clastic rocks is also used to interpret weathering conditions $[12]$ as $\mathrm{Th} / \mathrm{U}$ ratio in sedimentary rocks is expected to increase with increasing weathering [3] [54] [55] [56]. It is observed that during weathering and/or sedimentary recycling under oxidizing conditions, $\mathrm{U}^{4+}$ is relatively less soluble, converts to $\mathrm{U}^{6+}$, which is more soluble and thus rapidly dissolved and lost during sedimentation. For most upper crustal rocks, the Th/U ratio is typically about 3.5 to 4.0. Many types of sediment from active margin tectonic settings with major components of young undifferentiated crust have $\mathrm{Th} / \mathrm{U}$ ratio significantly below 3.5 accompanied by low $\mathrm{Th}$ and $\mathrm{U}$ contents, and this is interpreted as dominantly reflecting a low ratio in the source rocks [54] [57]. Low Th/U ratios are rather common in mantle-derived volcanic rocks and reflect the geochemically depleted nature of such reservoirs [58]. Workers like Wedephol (1991) [59] have also shown that the whole rock $\mathrm{Th} / \mathrm{U}$ ratio is a sensitive indicator of metamorphism in all types of rocks. The Th/U ratios may reach 8-10 in upper amphibolites facies and as high as 25 in the granulite facies. In cases where low $\mathrm{Th} / \mathrm{U}$ exists due to sedimentary process, it is likely that it resulted from $\mathrm{U}$ enrichment and accordingly this will be accompanied by high $U$ content reflecting the greater mobility of this element and vice versa. 
The average $\mathrm{Th} / \mathrm{U}$ ratio in the phyllites of Aravalli Supergroup ranges from 5.32 to 8.52 (DWP: 5.6, JMP: 6.2, UPP: 7.1, ZWP: 8.5, BWP: 5.3, TDP: 6.9, JHP: 8.2). The average $\mathrm{Th} / \mathrm{U}$ ratio of quartzites of Aravalli Supergroup ranges from 1.7 to 11.4 (DWQ: 11.3, JMQ: 1.7, UPQ: 4.9, ZWQ: 4.7, BWQ: 3.2, TDQ: 2.3, DBQ: 2.8 , and JHQ: 2.6). The average Th/U ratios in the clastic rocks of Aravalli Supergroup are higher than the $\mathrm{Th} / \mathrm{U}$ ratio of upper crustal rocks $(3.5-4.0)$ and can be interpreted either due to chemical weathering under oxidizing conditions in the depositional basin or source characteristics or accumulation of Th bearing minerals through sorting [54] [57]. The source rock for Aravalli Supergroup sediments is Banded Gneissic Complex (BGC). It has three main components i.e., granites, TTG and mafic enclaves which possess average $\mathrm{Th} / \mathrm{U}$ ratios as 4.26 , 6.26 and 1.06 respectively [60] which negates the possibility of source inheritance. The Th and $\mathrm{U}$ contents of Aravalli phyllites show positive correlation with each other. Moreover, there is strong to moderate positive correlation of the Th and $\mathrm{U}$ contents with $\mathrm{Al}_{2} \mathrm{O}_{3}$, both in quartzites and phyllites in each formation of Aravalli Supergroup. It suggests that Th bearing mineral phase (monazite) was selectively accumulated in the detritus which elevated the Th/U ratio. To further confirm this interpretation $\mathrm{Th} / \mathrm{U}$ ratios of Aravalli clastics are plotted against their Th abundances. In this diagram also (Figure 3), phyllites and most of the quartzite samples fall in the upper crust field $(\mathrm{Th} / \mathrm{U}>4)$. This again attests the inference that elevated $\mathrm{Th} / \mathrm{U}$ ratio in Aravalli clastics is due to monazite accumulation and not due to loss of $\mathrm{U}$ under oxidizing environment.

\section{8. $\mathrm{Al}_{2} \mathrm{O}_{3}-\left(\mathrm{CaO}^{*}+\mathrm{Na}_{2} \mathrm{O}\right)-\mathrm{K}_{2} \mathrm{O}$ or $\mathrm{A}-\mathrm{CN}-\mathrm{K}$ Ternary Diagram}

Most authors favour the use of $\mathrm{Al}_{2} \mathrm{O}_{3}-\left(\mathrm{CaO}^{*}+\mathrm{Na}_{2} \mathrm{O}\right)-\mathrm{K}_{2} \mathrm{O}(\mathrm{A}-\mathrm{CN}-\mathrm{K})$ ternary plot in evaluating the chemical weathering trends than simple comparison of numerical values [14] [50] [61] [62] [63] as geological systems are not simple and numerical calculations (indices) value may not adequately reflect their complexities.

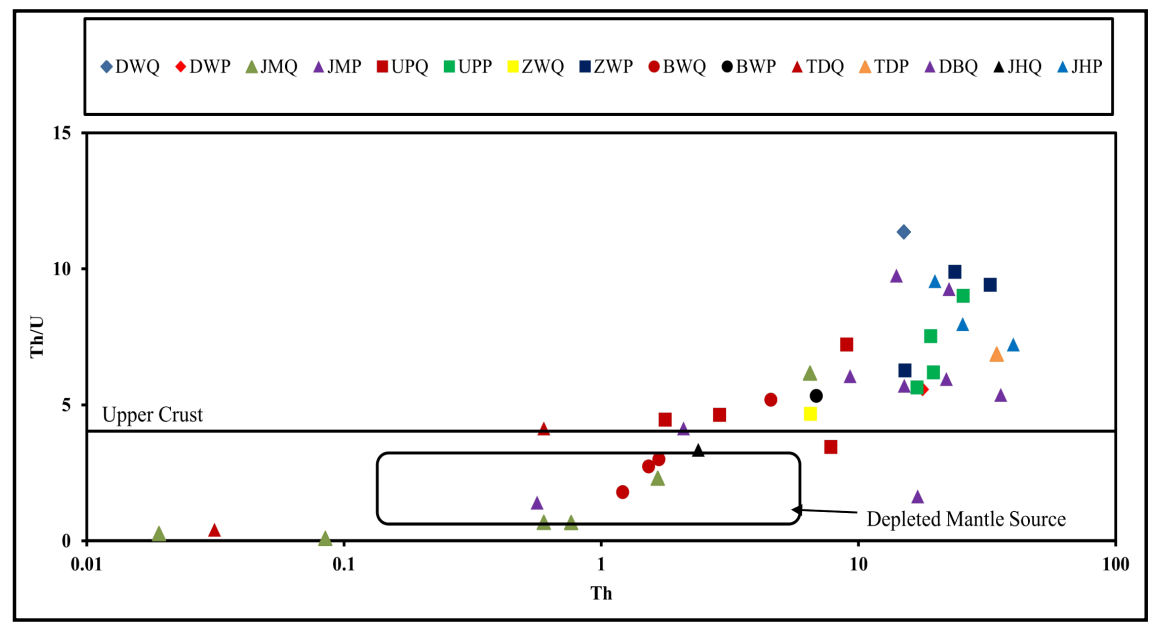

Figure 3. Plot of Th/U versus Th [12]. 
This diagram portrays the molar proportions of $\mathrm{Al}_{2} \mathrm{O}_{3}$ (A apex), $\mathrm{CaO}^{*}+\mathrm{Na}_{2} \mathrm{O}$ (CN apex) and $\mathrm{K}_{2} \mathrm{O}\left(\mathrm{K}\right.$ apex), where $\mathrm{CaO}^{*}$ represents $\mathrm{CaO}$ incorporated into silicate minerals [50] [14]. Plagioclase and $\mathrm{K}$-feldspar plot at $50 \% \mathrm{Al}_{2} \mathrm{O}_{3}$ on the left and right boundaries, respectively to form the "feldspar join". Biotite plots with K-feldspar, augite and amphiboles plot near the $\mathrm{CN}$ apex and calcite plots at the $\mathrm{Ca}$ apex. Illite and smectites plot on the diagram at $70 \%$ and $85 \% \mathrm{Al}_{2} \mathrm{O}_{3}$. The clay mineral groups, kaolin, chlorites and gibbsite plot at the A apex $(100 \%$ $\mathrm{Al}_{2} \mathrm{O}_{3}$ ). The initial weathering trends of igneous rocks are sub parallel to CN-A join as $\mathrm{Ca}$ and $\mathrm{Na}$ from plagioclase are leached from the profile in preference to $\mathrm{Al}_{2} \mathrm{O}_{3}$, thus the residues are enriched in $\mathrm{Al}_{2} \mathrm{O}_{3}$. As weathering progresses, clay minerals are produced at the expense of feldspars and bulk composition of soil/ sediments samples evolve up the diagram towards A apex, along the weathering trend. The most intensely weathered samples will therefore, plot highest on the diagram, reflecting the preponderance of aluminous clay minerals. The weathering trend intersects then A-K boundary once all plagioclase is weathered and then is redirected towards the A apex because $\mathrm{K}$ is extracted from the residues in preference to Al. Several workers [39] [63] [64] have proposed various approaches in order to ascertain the weathering trend in the A-CN-K plot, for a given set of data. Bhat and Ghosh (2001) [64], advocate the use of a best fit line through the data points as the probable weathering trend, while Roddaz et al. (2006) [63] define the weathering trend as line parallel to the A-CN join through samples with low $\mathrm{K}_{2} \mathrm{O}$ content. Fedo et al. (1995) [39] and Jayant and Rajamani (2003) [65] on the other hand follow the general trend line of Upper Continental Crust (UCC).

The A-CN-K plot is also useful for evaluating fresh rock composition and examining their weathering trends since unweathered primary igneous rocks have CIA values close to 50 [39] i.e. close to the feldspar join on A-CN-K diagram, backward projection of the weathered samples should lead to a point on the feldspar join which approximates plagioclase/K-feldspar ratios of their source rock. And also the amount of $\mathrm{K}$ enrichment and the palaeoweathering index prior to such enrichment can be ascertained from A-CN-K plot [39]. Because this type of $\mathrm{K}$-enrichment involves addition of $\mathrm{K}_{2} \mathrm{O}$ to aluminous clays, which follows a path towards the $\mathrm{K}_{2} \mathrm{O}$ apex of the triangle. $\mathrm{K}$-metasomatism of sediments can take two different paths representing either conversion of aluminous clay minerals (kaolinite as matrix) to illite and/or conversion of plagioclase to $\mathrm{K}$-feldspar. Both these processes result in the samples being enriched in $\mathrm{K}_{2} \mathrm{O}$ and therefore offset from the weathering trend. Conversions of secondary aluminum clay minerals to illite results in a CIA value lower than the pre-metasomatised one while in the second case, where $\mathrm{K}$ metasomatism involves replacement of plagioclase by K-feldspar, the CIA does not change because the process involves mole by mole substitution of $\mathrm{K}$ for $\mathrm{Ca}$ or $\mathrm{Na}$. An estimate of the $\mathrm{K}$-metasomatism can be made by drawing a line from $\mathrm{K}_{2} \mathrm{O}$ apex through individual data point, the intersection point of this line with the weathering path gives the pre-metasomatised CIA value, which can be directly read from the 
scale on the left. The difference between the pre-metasomatised and the current CIA values allows quantitative estimation of $\mathrm{K}$-enrichment in a rock.

In the A-CN-K triangular diagram, the data of the Aravalli Supergroup appears to be plotted in scattered form. Such patterns are interpreted to indicate derivation of detritus from different sources. However, close scrutiny of the diagram indicates that data points of individual formations show parallelism with A-CN or A-K axes.

Most of the samples of phyllites and quartzites of Aravalli Supergroup lie above the feldspar join in A-CN-K plot (Figure 4) from 50 to 75 (phyllite) and 50 to 98 (quartzite) values of CIA. Some of the phyllite samples of Jhamarkotra, Udaipur and Jharol formations (Figure 4) show effect of K-metasomatism as they are inclined towards $\mathrm{K}$ apex. The weathering trend of these sediments can be obtained by a best fit line of their data points as suggested by Bhat and Ghosh (2001) [64].

\section{Results and Discussion}

Sediments/sedimentary rocks are the final products of a chain of dynamic phenomena including weathering, ablation, transport, deposition and diagenesis. Therefore, chemical composition of the sedimentary rock is necessarily different from that of its parent rock because of the loss of the most soluble elements into water and the particle hydrodynamic sorting during transport by rivers to sea. After deposition, sediment may experience several mineral transformations during its burial diagenesis history. These transformations depend on the local physico-chemical conditions that prevail at a given time. Some of the primary minerals may be dissolved (feldspars) or re-crystallized (clays) while new ones precipitate in pores (quartz, carbonates, chlorites). Consequently, the composition of the sediments is modified according to the type and intensity of the different possible diagenetic reactions. Nonetheless, the dismantling of a given weathered rock (same parent rocks forming the drainage basin, same climatic conditions) may produce different types of sediments according to the energy and length of transport. Thus, the chemical composition of arkoses, greywackes and shales gives different CIA values in spite of their common source [66]. In order to avoid the particle sorting effect on the composition of the sediment, it is safer to rely upon the clay-rich mudstones for constraining the syn- and/or post-depositional processes.

The overall synthesis of geochemical data of Aravalli clastic rocks discussed, suggests low to extreme degree of chemical weathering in their source area. Close scrutiny of weathering indices reveal a pattern of change in the weathering intensity from base to top. The Delwara phyllites as well quartzites possess minimum CIA values (51.6, 57.4 respectively) whereas Bowa and Jharol clastics have maximum CIA values (BWP: 81.5, BWQ: 78.9, JHP: 81.6, JHQ: 76.3) (Table 2). The Bowa Formation is the second topmost sequence of middle and Jharol Formation is the topmost sequence of upper Aravalli Supergroup. With minor exceptions, other indices including PIA, CIW, and ICV nearly endorse 


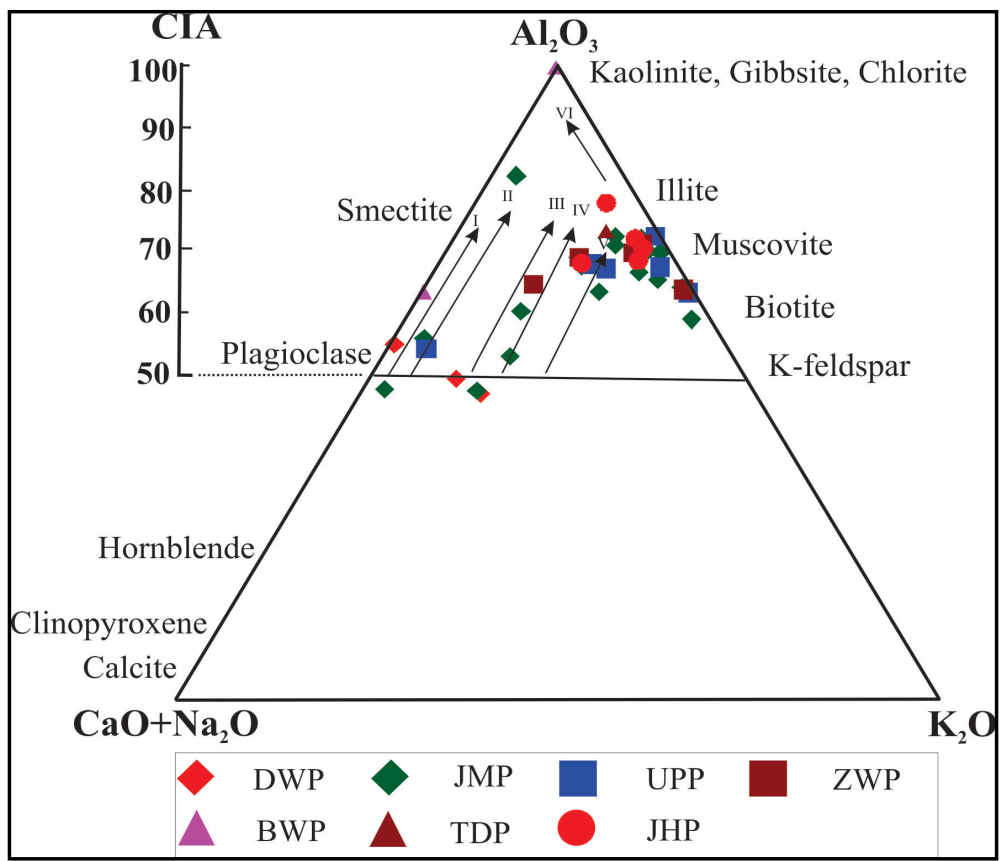

(a)

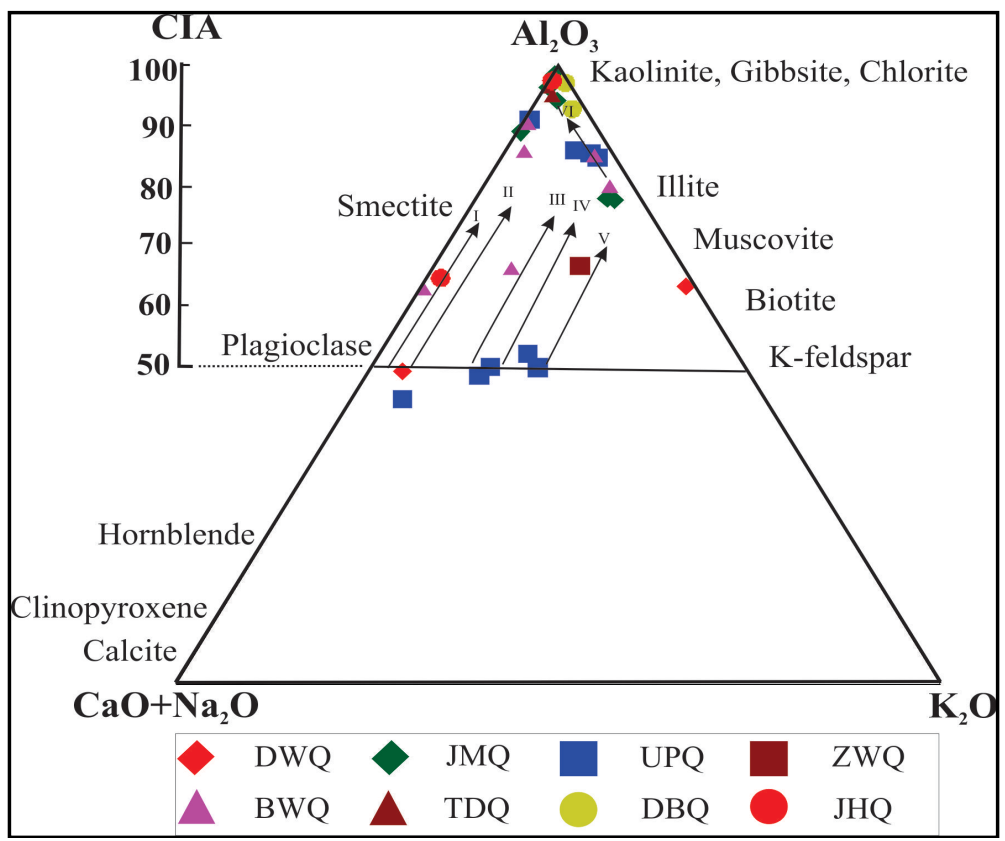

(b)

Figure 4. A-CN-K (in molecular proportion) ternary plot [14] for the Aravalli clastic sediments (a) Phyllite (b) Quartzite. $\mathrm{CIA}=\left[\mathrm{Al}_{2} \mathrm{O}_{3} / \mathrm{Al}_{2} \mathrm{O}_{3}+\mathrm{CaO}^{*}+\mathrm{Na}_{2} \mathrm{O}+\mathrm{K}_{2} \mathrm{O}\right] \times 100$. Arrows I-VI denote compositional trend of initial weathering profile of various rock types, I-Gabbro, II-Tonalite, III-Diorite, IV-Granodiorite, V-Granite and VIadvance weathering trend.

the inference adduced from CIA. However, A-CN-K diagrams fail to provide any emphatic relationship. Since Nesbitt's pioneer work defining Chemical Index of Alteration (CIA) [67] [13], several other indexes have been proposed 
Table 2. Major element oxides (in wt\%), trace elements (in ppm), weathering indices and Th/U ratio of the rocks of Aravalli Supergroup.

\begin{tabular}{|c|c|c|c|c|c|c|c|c|c|c|c|c|c|c|c|}
\hline \multirow[b]{2}{*}{$\begin{array}{l}\text { Sample/ } \\
\text { Element }\end{array}$} & \multicolumn{2}{|c|}{ Delwara } & \multicolumn{2}{|c|}{ Jhamarkotra } & \multicolumn{2}{|c|}{ Udaipur } & \multicolumn{2}{|c|}{ Zawar } & \multicolumn{2}{|c|}{ Bowa } & \multicolumn{2}{|c|}{ Tidi } & \multirow{2}{*}{$\begin{array}{c}\text { Debari } \\
\text { 苞 } \\
\text { 苞 } \\
\text { 岂 }\end{array}$} & \multicolumn{2}{|c|}{ Jharol } \\
\hline & 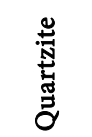 & 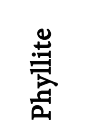 & 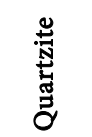 & 䃕 & 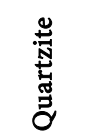 & 尝 & 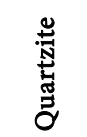 & 尝 & 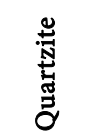 & 尝 & 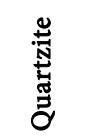 & 尝 & & 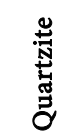 & \\
\hline $\mathrm{SiO}_{2}$ & 83.73 & 55.99 & 94.78 & 65.02 & 84.10 & 65.79 & 91.30 & 71.47 & 96.24 & 57.76 & 98.64 & 66.88 & 96.18 & 96.87 & 64.47 \\
\hline $\mathrm{Al}_{2} \mathrm{O}_{3}$ & 9.53 & 11.58 & 1.76 & 15.27 & 8.37 & 18.24 & 5.70 & 16.45 & 2.64 & 14.35 & 1.30 & 17.50 & 2.58 & 2.06 & 21.66 \\
\hline $\mathrm{TiO}_{2}$ & 0.10 & 1.37 & 0.02 & 0.80 & 0.16 & 0.71 & 0.17 & 0.60 & 0.05 & 0.92 & 0.00 & 0.96 & 0.05 & 0.06 & 0.96 \\
\hline $\mathrm{Fe}_{2} \mathrm{O}_{3}$ & 1.29 & 14.42 & 0.69 & 7.59 & 1.71 & 6.50 & 0.84 & 5.63 & 0.33 & 14.20 & 0.02 & 8.39 & 0.61 & 0.53 & 6.59 \\
\hline $\mathrm{MnO}$ & 0.02 & 0.20 & 0.03 & 0.09 & 0.02 & 0.11 & 0.02 & 0.04 & 0.02 & 0.08 & 0.03 & 0.01 & 0.03 & 0.02 & 0.04 \\
\hline $\mathrm{MgO}$ & 0.15 & 5.59 & 0.89 & 4.09 & 0.67 & 2.68 & 0.16 & 1.15 & 0.07 & 10.04 & 0.01 & 1.39 & 0.47 & 0.05 & 1.12 \\
\hline $\mathrm{CaO}$ & 0.55 & 6.35 & 1.72 & 2.21 & 0.59 & 0.62 & 0.20 & 0.23 & 0.10 & 0.62 & 0.04 & 0.20 & 0.04 & 0.05 & 0.22 \\
\hline $\mathrm{Na}_{2} \mathrm{O}$ & 3.26 & 2.52 & 0.02 & 1.22 & 2.59 & 1.30 & 0.46 & 0.72 & 0.26 & 1.94 & 0.01 & 1.23 & 0.01 & 0.37 & 0.74 \\
\hline $\mathrm{K}_{2} \mathrm{O}$ & 1.39 & 1.83 & 0.11 & 3.54 & 1.75 & 4.55 & 1.16 & 3.60 & 0.32 & 0.04 & 0.01 & 3.36 & 0.08 & 0.03 & 4.12 \\
\hline $\mathrm{P}_{2} \mathrm{O}_{5}$ & 0.01 & 0.16 & 0.02 & 0.18 & 0.05 & 0.23 & 0.03 & 0.11 & 0.01 & 0.09 & 0.01 & 0.09 & 0.02 & 0.01 & 0.09 \\
\hline CIA & 57.40 & 51.58 & 63.69 & 64.89 & 66.99 & 66.23 & 67.64 & 71.47 & 78.91 & 81.47 & 95.52 & 71.35 & 95.26 & 81.57 & 76.26 \\
\hline PIA & 73.46 & 51.38 & 65.79 & 78.83 & 70.85 & 84.87 & 78.45 & 89.42 & 84.75 & 81.58 & 96.57 & 84.40 & 99.02 & 82.06 & 90.95 \\
\hline CIW & 75.54 & 56.86 & 67.24 & 82.89 & 76.01 & 87.69 & 83.50 & 91.98 & 85.55 & 81.66 & 96.61 & 87.98 & 99.06 & 82.37 & 93.33 \\
\hline ICV & 1.18 & 4.30 & 1.89 & 2.09 & 1.04 & 1.57 & 0.80 & 1.14 & 0.53 & 3.61 & 0.09 & 1.36 & 0.94 & 0.64 & 1.05 \\
\hline $\mathrm{Th}$ & 15.01 & 17.77 & 1.60 & 19.40 & 5.4 & 20.30 & 6.52 & 23.82 & 2.25 & 6.86 & 0.32 & 34.51 & 1.33 & 1.2 & 28.44 \\
\hline $\mathrm{U}$ & 1.32 & 3.20 & 0.81 & 4.12 & 1.13 & 2.89 & 1.40 & 2.76 & 0.67 & 1.29 & 0.11 & 5.03 & 0.45 & 0.36 & 3.61 \\
\hline $\mathrm{Th} / \mathrm{U}$ & 11.35 & 5.56 & 1.69 & 6.24 & 4.94 & 7.09 & 4.67 & 8.52 & 3.18 & 5.32 & 2.26 & 6.87 & 2.77 & 2.64 & 8.24 \\
\hline
\end{tabular}

based on mineralogical or chemical data to evaluate the intensity of alteration. Nevertheless, the CIA remains, by far, the most widely used one.

The major factors which control the intensity of weathering are heavy rainfall, vegetation cover, relief, high surface temperature and high atmospheric $\mathrm{P}_{\mathrm{CO} 2}$. A low to moderate degree of weathering as indicated by the composition of lower Aravalli do not suggest more $\mathrm{CO}_{2}$ enriched atmosphere and usually high surface temperature in absence of vegetation. Various geochemical parameters such as CIA, CIW, PIA, Th/U ratio, ICV values as described above suggest moderate climatic conditions during the deposition for the sediments of Lower and Middle Aravalli and the Upper Aravalli formation reflect the extreme weathering in the source region. The higher values of ICV $(>1)$ for Aravalli sediments indicate that they are compositionally immature and possibly derive from a tectonically active environments where sediment recycling is not active. High $\mathrm{Th} / \mathrm{U}$ ratios in the Aravalli clastics are due to the low mobility of Thorium (which got accumulated through hydraulic sorting) under all environmental conditions, mainly due to the high stability of the insoluble oxide $\mathrm{ThO}_{2}$ and the strongly resistant nature of its carrier minerals such as monazite. 
The stratigraphic division of the lithosequences of Aravalli fold belt has been in debate since the elevation of their status from group to supergroup [68], in particular about the status of Debari Formation, as given below.

Heron (1953) [30] considered Debari Formation (his Debari Group) as outliers of Delhi System. Roy et al. (1988) [34] considered Debari Formation as basal member of the upper division of Aravalli Supergroup (Figure 5). However, Roy and Jhakhar (2002) [38], further modified the succession of Aravalli Supergroup, got divided it into three divisions and placed Debari Formation as the basal member of uppermost division. Although all the modifications in the succession of Aravalli Supergroup are claimed to have been done taking into account several geological parameters, but still there is not consensus among the workers for any of the succession.

A critical examination of chemical weathering trend inferred from weathering indices of clastic rocks of various formations of Aravalli Supergroup in present study reveals that the rocks of Delwara Formation are almost unweathered, Jhamarkotra and Udaipur largely moderate, Tidi and Jharol are intense and Bowa and Debari are highly intense. In the present stratigraphic succession, this variation in chemical weathering is difficult to explain as it requires protuberance in source area followed by peneplanation stage and then moderate uplift. If the samples are re-arranged according to the succession given by Roy (1988) [34], the chemical weathering appears to be episodic in three phases. Sedimentary deposits of each phase appear to be product of uplift and progressive

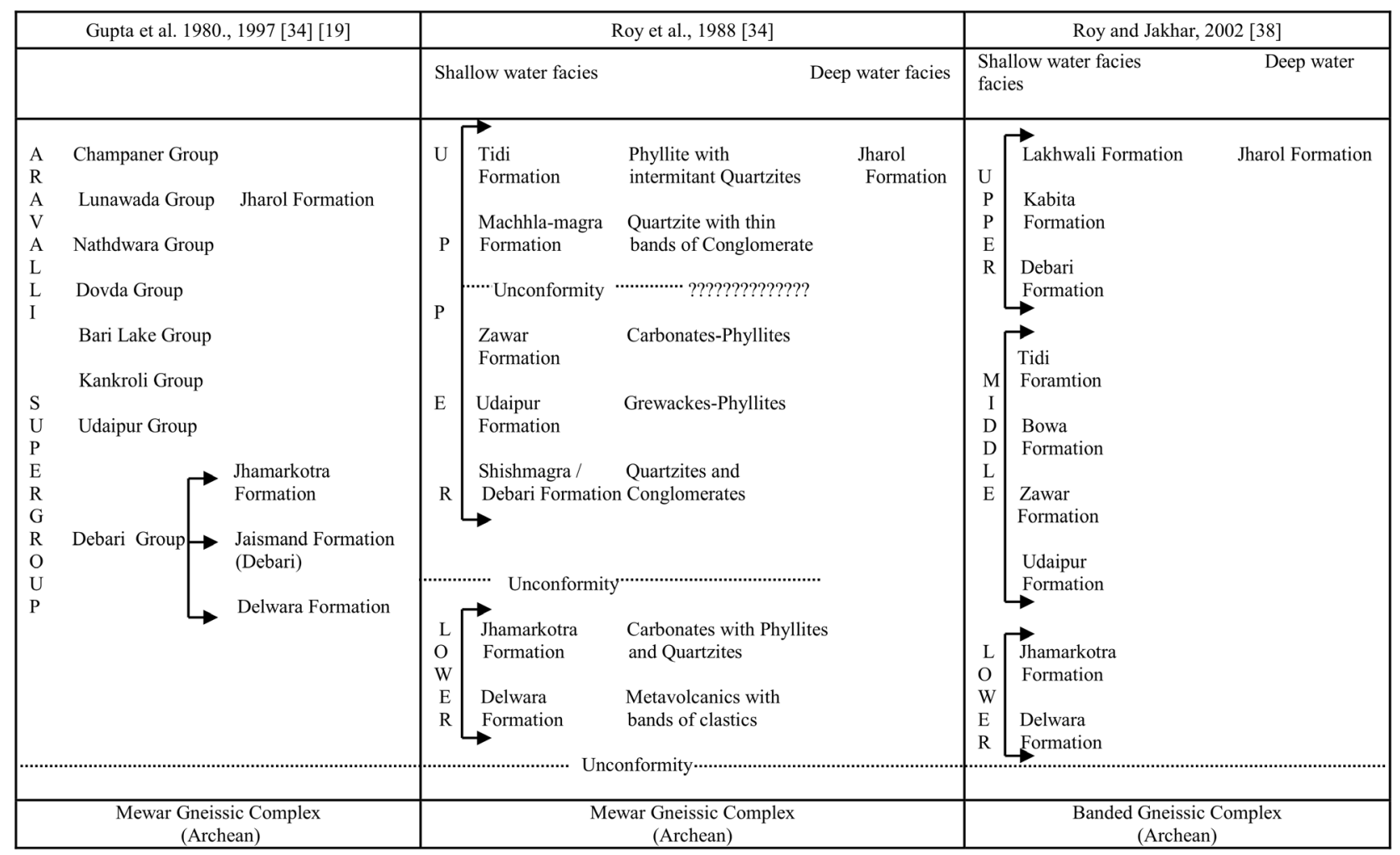

Figure 5. Comparison of stratigraphic succession of the Aravalli Supergroup proposed by different workers [19] [34] [38] [69]. 
peneplanation of the source region. It is argued and observed that there were consistent attempts within the Indian shield to change its evolution style from typical Archean greenstone to Proterozoic Wilson Cycle [22] [70]. It appears that a rift developed within BGC due to the upwelling of plume. In this rift deposition of volcano-sedimentary lithopackage of Delwara and carbonaceous medium to fine clastic sequence of Jhamarkotra Formations took place in the immediate proximal and slightly distal parts of the basin. Physical weathering was active in the source region. The highland area of the source region became gradually flat that paved the way for intense chemical weathering. Relatively large distance of transport and intense chemical weathering led to the deposition of conglomerate-quartzite sequence of Debari Formation uniformly over Jhamarkotra Formation. Reactivation of plume produced highland in the source region which caused the deposition of Udaipur and Zawar formation that culminated after the deposition of Bowa sequence (another conglomerate-quartzite horizon similar to Debari sequence). Third and final episode of plume induced uplift supplied the detritus for the upper sequence of Aravalli Supergroup. During the period of Aravalli sedimentation, the basin continues to become deeper till the formation of transitional oceanic crust represented by Jharol maficultramafic sequence in the distal part. The abrupt closure of Aravalli basin was probably due to the change in plume geometry or plume position led to the opening of another basin (Delhi basin) parallel in orientation and adjacent to Aravalli basin on its western side [71]. The cyclic weathering history of Aravalli sediments may provide a testimony for the episodic evolution of Aravalli basin. The chemo-stratigraphic sequence evolved in this study is more relevant and the placement of the Debari Formation above the Tidi Formation [34] is conjectural. However this interpretation requires further study involving trace element geochemistry and isotopic analysis. The trace element abundances may be helpful in discriminating temporal provenance changes whereas $\mathrm{U}-\mathrm{Pb}$ dating may fingerprint chronostratigraphy of Aravalli Supergroup and protolithic signature.

\section{Conclusion}

The geochemical indices used to constrain weathering intensity in the source region prescribe three episodes of chemical weathering. Each cycle began with physical weathering and culminated in intense chemical weathering. The conglomerate/quarzite horizons occurring at various levels in the stratigraphic hierarchy show maximum chemical weathering and thus mark the end of a weathering cycle. This interpretation advocates that stratigraphic classification proposed by Roy (1988) [34] is more appropriate than the subsequent revised versions as it properly explains protuberance and peneplanation event taking place in the source region in response to plume induced tectonics.

\section{Acknowledgements}

The authors are thankful to the Chairmen, Department of Geology, AMU, Aligarh, 
for providing requisite research facilities. We are also indebted to Dr. A.V. Mudholkar, Chief Scientist, NIO, Goa, Dr. Indra S. Sen, IIT, Kanpur and Dr. Srinivas Sharma, Principal Scientist, NGRI, Hyderabad for the sample analysis. Dr. Tavheed Khan, PDF, NGRI, Hyderabad, is thanked for fruitful help during the course of this study. University Grant Commission, New Delhi is acknowledged for financial support in the form of Basic Scientific Research (BSR) fellowship to PKS.

\section{References}

[1] Hayashi, K., Fujisawa, H., Holland, H. and Ohmoto, H. (1997) Geochemistry of $\sim 1.9$ Ga Sedimentary Rocks from Northeastern Labrador, Canada. Geochimica et Cosmochimica Acta, 61, 4115-4137. https://doi.org/10.1016/S0016-7037(97)00214-7

[2] Armstrong-Altrin, J.S. (2009) Provenance of Sands from Cazones, Acapulco, and Bahía Kino Beaches, México. Revista Mexicana de Ciencias Geológicas, 26, 764-782.

[3] Taylor, S.R and McLennan, S.M. (1985) The Continental Crust: Its Composition and Evolution. Blackwell, London, 311.

[4] Dickinson, W.R. (1985) Interpreting Relations from Detrital Modes of Sandstone. In: Zuffa, G.G., Ed., Provenance of Arenites, Dordrecht-Boston-Lancaster, Reidel, 333-361. https://doi.org/10.1007/978-94-017-2809-6_15

[5] Cullers, R.L., Barrett, T., Carlson, R. and Robinson, B. (1987) Rare-Earth Element and Mineralogic Changes in Holocene Soil and Stream Sediment: A Case Study in the Wet Mountains Region, Colorado, USA. Chemical Geology, 63, 275-297. https://doi.org/10.1016/0009-2541(87)90167-7

[6] Wronkiewicz, D.J. and Condie, K.C. (1987) Geochemistry of Archean Shales from the Witwatersrand Supergroup, South Africa: 421. Source Area Weathering and Provenance. Geochimica Cosmochimica Acta, 51, 2401-2416. https://doi.org/10.1016/0016-7037(87)90293-6

[7] Bhatia, M.R. (1983) Plate Tectonics and Geochemical Composition of Sandstones. Journal of Geology, 91, 611-612. https://doi.org/10.1086/628815

[8] Condie, K.C., Noll Jr., P.D. and Conway, C.M. (1992) Geochemical and Detrital Mode Evidence for Two Sources of Early Proterozoic Sedimentary Rocks from the Tonto Basin Supergroup, Central Arizona. Sedimentary Geology, 77, 51-76. https://doi.org/10.1016/0037-0738(92)90103-X

[9] Condie, K.C. (1993) Chemical Composition and Evolution of the Upper Continental Crust: Contrasting Results from Surface Samples and Shales. Chemical Geology, 104, 1-37. https://doi.org/10.1016/0009-2541(93)90140-E

[10] Cullers, R.L. and Podkovyrov, V.N. (2000) Geochemistry of the Mesoproterozoic Lakhanda Shales in Southern Yakutia, Russia: Implications for Mineralogical and Provenance Control, and Recycling. Precambrian Research, 104, 77-93. https://doi.org/10.1016/S0301-9268(00)00090-5

[11] Dickinson, W.R., Beard, L.S., Brakenridge, G.R., Erjavec, J.L., Ferguson, R.C., Inman, K.F., Knepp, R.A., Lindberg, F.A. and Ryberg, P.T. (1983) Provenance of North American Phanerozoic Sandstones in Relation to Tectonic Setting. Geological Society of America Bulletin, 94, 222-235. https://doi.org/10.1130/0016-7606(1983)94<222:PONAPS $>2.0 . C O ; 2$

[12] McLennan, S.M., Hemming, S., McDaniel, D.K and Hanson, G.N. (1993) Geochemical Approaches to Sedimentation, Provenance and Tectonics. Geological Society of America Special Paper, 284, 21-40. https://doi.org/10.1130/SPE284-p21 
[13] Nesbitt, H.W. and Young, G.M. (1982) Early Proterozoic Climates and Plate Motion Inferred from Major Element Chemistry of Lutites. Nature, 299, 715-717. https://doi.org/10.1038/299715a0

[14] Nesbitt, H.W. and Young, G.M. (1984) Prediction of Some Weathering Trend of Plutonic and Volcanic Rocks Based on Thermodynamic and Kinetic Consideration. Geochimica et Cosmochimica Acta, 48, 1523-1534. https://doi.org/10.1016/0016-7037(84)90408-3

[15] Nesbitt, H.W., Young, G.M., McLennan, S.M. and Keays, R.R. (1996) Effects of Chemical Weathering and Sorting on the Petrogenesis of Siliciclastic Sediments, with Implications for Provenance Studies. Journal of Geology, 104, 525-542. https://doi.org/10.1086/629850

[16] Quasim, M.A., Khan, I. and Ahmad, A.H.M. (2017) Integrated Petrographic, Mineralogical, and Geochemical Study of the Upper Kaimur Group of Rocks, Son Valley, India: Implications for Provenance, Source Area Weathering and Tectonic Setting. Journal of Geological Society of India, 90, 467-484. https://doi.org/10.1007/s12594-017-0740-6

[17] Roser, B.P. and Korsch, R.J. (1988) Provenance Signatures of Sandstone-Mudstone Suites Determined Using Discrimination Function Analysis of Major-Element Data. Chemical Geology, 67, 119-139. https://doi.org/10.1016/0009-2541(88)90010-1

[18] Naqvi, S.M. and Rogers, J.J.W. (1987) Precambrian Geology of India. Oxford University Press, New York, 223.

[19] Gupta, S.N., Arora, Y.K., Mathur, R.K., Iqballuddin, Prasad, B., Sahai, T.N. and Sharma, S.B. (1997) The Precambrian Geology of the Aravalli Region; Southern Rajasthan and Northeastern Gujarat. Geological Survey of India Memoir, 123262.

[20] Ahmad, T. and Rajamani, V. (1991) Geochemistry and Petrogenesis of the Basal Aravalli Volcanics near Nathdwara, Rajasthan, India. Precambrian Research, 49, 185-204. https://doi.org/10.1016/0301-9268(91)90062-F

[21] Hamatteh, A.Z.S.H. (2003) Geochemistry and Petrogenesis of Mafic Magmatic Rocks of the Jharol Belt, India: Geodynamic Implication. Journal of Asian Earth Sciences, 25, 557-581. https://doi.org/10.1016/j.jseaes.2004.05.006

[22] Raza, M. and Khan, M.S. (1993) Basal Aravalli Volcanism: Evidence for an Abortive Attempt to Form Proterozoic Ensialic Greenstone Belt in the Northwestern Part of Indian Shield. Journal of the Geological Society of India, 42, 493-512.

[23] Shekhawat, L.S., Pandit, M.K. and Joshi, D.W. (2007) Geology and Geochemistry of Palaeoproterozoic Low-Grade Metabasic Volcanic Rocks from Salumber Area, Aravalli Supergroup, NW India. Journal of Earth Science System, 6, 511-524. https://doi.org/10.1007/s12040-007-0047-x

[24] Absar, N. and Sreenivas, B. (2015) Petrology and Geochemistry of Greywackes of the 1.6 Ga Middle Aravalli Supergroup, Northwest India: Evidence for Active Margin Processes. International Geology Review, 57, 134-158. https://doi.org/10.1080/00206814.2014.999355

[25] Banerjee and Bhattacharya (1994) Petrology and Geochemistry of Greywackes from the Aravalli Supergroup, Rajasthan, India and the Tectonic Evolution of a Proterozoic Sedimentary Basin. Precambrian Research, 67, 11-35. https://doi.org/10.1016/0301-9268(94)90003-5

[26] Gopalan, K., Macdougall, J.D., Roy, A.B. and Murali, A.V. (1990) Sm-Nd Evidences for $3.3 \mathrm{Ga}$ Old Rocks in Rajasthan, Northwestern India. Precambrian Research, 48, 287-297. https://doi.org/10.1016/0301-9268(90)90013-G 
[27] Roy, A.B. and Kröner, A. (1996) Single Zircon Evaporation Ages Constraining the Growth of the Archaean Aravalli Craton, Northwestern Indian Shield. Geological Magazine, 133, 333-342. https://doi.org/10.1017/S0016756800009067

[28] Wiedenbeck, M. and Goswami, J.N. (1994) High-Precision 207Pb/206Pb Zircon Geochronology Using a Small Ion Microprobe. Geochimica et Cosmochimica Acta, 58, 2135-2141. https://doi.org/10.1016/0016-7037(94)90291-7

[29] Wiedenbeck, M., Goswami, J.N. and Roy, A.B. (1996) Stabilization of the Aravalli Craton of Northwestern India at $2.5 \mathrm{Ga}$ : An Ion Microprobe Zircon Study. Chemical Geology, 129, 325-340. https://doi.org/10.1016/0009-2541(95)00182-4

[30] Heron, A.M. (1953) Geology of Central Rajputana. Memoir Geological Survey of India, 79, 1-389.

[31] Poddar, B.C. (1966) An Example of Contrasted Tectonic Regimes from Precambrians of Udaipur District, Rajasthan. Indian Minerals, 20, 192-194.

[32] Roy, A.B. (1990) Evolution of the Precambrian Crust of the Aravalli Mountain Range. In: Naqvi, S.M., Ed., Precambrian Continental Crust and Its Economic Resources, Development in Precambrian Geology, Elsevier, Amsterdam, 327-348. https://doi.org/10.1016/S0166-2635(08)70173-7

[33] Roy, A.B. and Paliwal, B.S. (1981) Evolution of Lower Proterozoic Epicontinental Deposits: Stromatolite-Bearing Aravalli Rocks of Udaipur, Rajasthan, India. Precambrian Research, 14, 49-74. https://doi.org/10.1016/0301-9268(81)90035-8

[34] Roy, A.B., Paliwal, B.S., Shekhawat, S.S., Nagori, D.K., Golani, P.R. and Bejarniya, B.R. (1988) Stratigraphy of the Aravalli Supergroup in the Type Area. Memoir Geological Society of India, 7, 121-138.

[35] Roy, A.B., Sharma, B.L., Paliwal, B.S., Chauhan, N.K., Nagori, D.K., Golani, P.R., Bejarniya, B.R., Bhu, H. and Sabah, M.A. (1993) Lithostratigraphy and Tectonic Evolution of Aravalli Supergroup-A Protogeosynclinal Sequence. In: Cassyap, S.M. and Valdiya, K.S., Eds., Rifted Basins and Aulcogens, Gyanodaya Prakasan, Nainital, 73-90.

[36] Sreenivas, B., Roy, A.B. and Srinivasan, R. (2001a) Geochemistry of Sericite Deposits at the Base of Proterozoic Aravalli Supergroup, Rajasthan, India: Evidence for metamorphosed Precambrian Paleosols. Proceeding Indian Academy of Science (Earth \& Planetary Science), 110, 39-61.

[37] Roy, A.B. (2000) Geology of the Paleoproterozoic Aravalli Supergroup of Rajasthan and Northern Gujarat. In: Deb, M., Ed., Crustal Evolution and Metallogeny in the Northwestern Shield, Narosa Publishing House, New Delhi, 87-114.

[38] Roy, A.B. and Jakhar, S.R. (2002) Geology of Rajasthan (Northwest India) Precambrian to Recent. Scientific Publishers (India), Jodhpur, 421.

[39] Fedo, C.M., Nesbitt, H.W. and Young, G.M. (1995) Unraveling the Effects of Potassium Metasomatism in Sedimentary Rocks and Paleosols, with Implications for Weathering Conditions and Provenance. Journal of Geology, 23, 921-924. https://doi.org/10.1130/0091-7613(1995)023<0921:UTEOPM>2.3.CO;2

[40] Harnois, L. (1988) The CIW, Index: A New Chemical Index of Weathering. Sedimentary Geology, 55, 319-322. https://doi.org/10.1016/0037-0738(88)90137-6

[41] Cox, R. and Lowe, D.R. (1995) A Conceptual Review of Regional Scale Controls on the Compositions of Clastic Sediments and the Co-Evolution of Continental Blocks and Their Sedimentary Cover. Journal of Sedimentary Research, 65, 1-12.

[42] Ruxton, B.P. (1968) Measures of the Degree of Chemical Weathering of Rocks. Journal of Geology, 76, 518-527. https://doi.org/10.1086/627357 
[43] Vogt, T. (1927) Sulitjelmafeltets geologi og petrografi. Norges Geologiske Undersokelse, 121, 1-560. (In Norwegian, with English Abstract)

[44] Parker, A. (1970) An Index of Weathering for Silicate Rocks. Geological Magazine, 107, 501-504. https://doi.org/10.1017/S0016756800058581

[45] Nesbitt, H.W., Fedo, C.M. and Young, G.M. (1997) Quartz and Feldspar Stability, Steady and Non-Steady State Weathering and Petrogenesis of Siliciclastic Sands and Muds. Journal of Geology, 105, 173-191. https://doi.org/10.1086/515908

[46] Singh, P. (2009) Major, Trace and REE Geochemistry of the Ganga River Sediments: Influence of Provenance and Sedimentary Processes. Chemical Geology, 266, 242-255. https://doi.org/10.1016/j.chemgeo.2009.06.013

[47] Singh, P. (2010) Geochemistry and Provenance of Stream Sediments of the Ganga River and Its Major Tributaries in the Himalayan Region, India. Chemical Geology, 269, 220-236. https://doi.org/10.1016/j.chemgeo.2009.09.020

[48] Maynard, J.B. (1992) Chemistry of Modern Soils as a Guide to Interpreting Precambrian Paleosols. Journal of Geology, 100, 279-289. https://doi.org/10.1086/629632

[49] Maynard, J.B., Sutton, S.J., Robb, L.J., Ferraz, M.F. and Meyer, F.M. (1995) A Paleosol Developed on Hydrothermally Altered Granite from the Hinterland of the Witwatersrand Basin: Characteristics of a Source of Basin Fill. Journal of Geology, 103, 357-377. https://doi.org/10.1086/629757

[50] Nesbitt, H.W. and Young, G.M. (1989) Formation and Diagenesis of Weathering Profiles. Journal of Geology, 97, 129-147. https://doi.org/10.1086/629290

[51] Mongelli, G., Cullers, R.L. and Muelheisen, S. (1996) Geochemistry of Late Cretaceous-Oligocenic Shales from the Varicolori Formation, Southern Apennines, Italy: Implications for Mineralogical, Grain-Size Control and Provenance. European Journal of Mineralogy, 8, 733-754. https://doi.org/10.1127/ejm/8/4/0733

[52] Cox, R., Lowe, D.R. and Cullers, R.D. (1995) The Influence of Sediment Recycling and Basement Composition on Evolution of Mudrock Chemistry in the Southwestern United States. Geochimica et Cosmochimica Acta, 59, 2919-2940. https://doi.org/10.1016/0016-7037(95)00185-9

[53] McLennan, S.M. and Taylor, S.R. (1991) Sedimentary Rocks and Crustal Evolution, Tectonic Setting and Secular Trends. Journal of Geology, 99, 1-21. https://doi.org/10.1086/629470

[54] McLennan, S.M., Hemming, S., Taylor, S.R. and Eriksson, K.A. (1995) Early Proterozoic Crustal Evolution: Geochemical and $\mathrm{Nd}-\mathrm{Pb}$ Isotopic Evidence from Metasedimentary Rocks Southwestern North America. Geochimica et Cosmochimica Acta, 59, 1153-1173. https://doi.org/10.1016/0016-7037(95)00032-U

[55] McLennan, S.M., Taylor, S.R., Mcculloch, M.T. and Maynard, J.B. (1990) Geochemical and Nd-Sr Isotopic Composition of Deep Sea Turbitites: Crustal Evolution and Plate Tectonic Associations. Geochimica et Cosmochimica Acta, 54, 2015-2050. https://doi.org/10.1016/0016-7037(90)90269-Q

[56] McLennan, S.M. (1989) Rare Earth Elements in Sedimentary Rocks. Influence of Provenance and Sedimentary Processes. Reviews in Mineralogy, 21, 169-200.

[57] McLennan, S.M., Taylor, S.R. and Kroner, A. (1983) Geochemical Evolution of Archean Shales from South Africa, I, the Swaziland and Pogola Supergroups. Precambrian Research, 22, 93-124. https://doi.org/10.1016/0301-9268(83)90060-8

[58] Newman, S., Macdougall, J.D. and Finkel, R.C. (1984) $230^{\text {Th }}-238$ U Disequilibrium in Island Arcs: Evidence from the Aleutians and the Marianas. Nature, 308, 268-270. https://doi.org/10.1038/308268a0 
[59] Wedepohl, K.H. (1991) Chemical Composition and Fractionation of the Continental Crust. Geologische Rundschow, 8, 207-223. https://doi.org/10.1007/BF01829361

[60] Raza, M., Khan, A.N. and Bharadwaj, V.R. (2008) Geochemistry of Pelites of Bhilwara-Vindhyan Terrain, South Eastern Rajasthan and Its Implications for Provenance Characteristics, Tectonic Conditions and Paleoclimate during Archaean Proterozoic Time. Major Research Project by the Union Grant Commission, India. (Report Unpublished)

[61] Raza, M., Ahmad, A.H.M., Khan, M.S. and Khan, F. (2011) Geochemistry and Detrital Modes of Proterozoic Sedimentary Rocks, Bayana Basin, North Delhi Fold Belt: Implications for Provenance and Source-Area Weathering, International Geology Review, 54, 111-129. https://doi.org/10.1080/00206814.2010.517044

[62] Raza, M., Bharadwaj, V.R., Ahmad, A.H.M., Mondal, M.E.A., Khan, A. and Khan, M.S. (2010) Provenance and Weathering History of Archaean Naharmagra Quartzite of Aravalli craton, NW Indian Shield: Petrographic and Geochemical Evidence. Geochemical Journal, 44, 331-345. https://doi.org/10.2343/geochemj.1.0075

[63] Roddaz, M., Viers, J., Brusset, S., Baby, P., Boucayrand, C. and Herail, G. (2006) Controls on Weathering and Provenance in the Amazonian Foreland Basin: Insights from Major and Trace Element Geochemistry of Neogene Amazonian Sediments. Chemical Geology, 22, 31-65. https://doi.org/10.1016/j.chemgeo.2005.08.010

[64] Bhat, M.I. and Ghosh, S.K. (2001) Geochemistry of 2.51 Ga Old Rampur Group Pelites, Western Himalayas: Implications for Their Provenance and Weathering. Precambrian Research, 108, 1-16. https://doi.org/10.1016/S0301-9268(00)00139-X

[65] Jayant, K., Tripathi and Rajamani, V. (2003) Geochemistry of Proterozoic Delhi Quartzites: Implications for the Provenance and Source Area Weathering. Journal of the Geological Society of India, 62, 215-226.

[66] Meunier, A., Kaner, L., Hubert, F., Albani, A.E. and Pret, D. (2013) The Weathering Intensity Scale (WIS): An Alternative Approach of the Chemical Index of Alteration (CIA). American Journal of Science, 313, 113-143. https://doi.org/10.2475/02.2013.03

[67] Nesbitt, H.W. and Wilson, R.E. (1992) Recent Weathering of Basalts. American Journal of Science, 292, 740 -777. https://doi.org/10.2475/ajs.292.10.740

[68] Mathur, R.K., Iqbaluddin, Bhattacharjee, N.B. and Jayaram, B.N. (1973) Stratigraphy and Classification of Aravalli Supergroup in Parts of Udaipur District, Rajasthan. Sem. Recent Advances in Geology of Rajasthan and Gujrat, Jaipur, Abstract, 2.

[69] Gupta, S.N., Arora, Y.K., Mathur, R.K., Iqballuddin, Prasad, B., Sahai, T.N. and Sharma, S.B. (1980) Lithostratigraphic Map of the Aravalli Region. Geological Survey of India, Kolkata.

[70] Raza, M., Jafri, S.H., Alvi, S.H. and Khan, M. (1993) Geodynamic Evolution of Indian Shield during Proterozoic: Geochemical Evidence from the Mafic Volcanic Rocks. Journal of the Geological Society of India, 41, 455-469.

[71] Fatima, S. and Khan, M.S. (2012) Petrographic and Geochemical Characteristics of Mesoproterozoic Kumbalgarh Clastic Rocks, NW Indian Shield: Implications for Provenance, Tectonic Setting and Crustal Evolution. International Geology Review, 54, 1113-1144. https://doi.org/10.1080/00206814.2011.623032 